\title{
STRATEGI KREATIF ORANG TUA SINGLE PARENT DALAM MEMBANGUN SIKAP EMPATI ANAK SELAMA MASA PANDEMI COVID-19
}

\author{
SINGLE PARENT PARENTS CREATIVE STRATEGY IN BUILDING AN \\ ATTITUDE OF CHILDHOOD DURING THE COVID-19 PANDEMIC PERIOD
}

\author{
Sari Puteri Deta Larastati \\ Universitas Islam Negeri Sunan Kalijaga Yogyakarta, Indonesia \\ Email: sariputridetalarastati@gmail.com \\ Erni Munastiwi \\ Universitas Islam Negeri Sunan Kalijaga Yogyakarta, Indonesia \\ Email: erni.munastiei@uin-suka.ac.id
}

\begin{abstract}
Abstrak
Penelitian ini bertujuan untuk mengetahui bagaimana strategi kreatif orang tua yang berstatus single parent dalam membangun sikap empati anak selama masa pandemi COVID-19. Penelitian ini menggunakan metode penelitian kualitatif dengan tipe fenomenologi. Hasil penelitian menunjukkan bahwa bentuk strategi kreatif orang tua tunggal dalam membangun sikap empati anak di masa pandemi dimulai dengan pelatihan merawat tanaman, hewan, dan membantu orang tua di rumah. Sedangkan mempraktekkan toleransi bisa dimulai dengan mengajarkan anak menghargai perbedaan, kemudian mempraktekkan toleransi, dilakukan dengan menghargai usaha dan kemampuan anaknya. Hormati anaknya saat belajar puasa meski tidak seharian penuh. Keadaan ini akan membuat anak melakukan sesuatu dengan rasa aman dan nyaman tanpa harus mempertimbangkan tuntutan dari orang tua.
\end{abstract}

Kata Kunci: orang tua, empati, COVID-19

\begin{abstract}
This study aims to determine how the creative strategies of parents who are single parent status in building empathy attitude of children during the COVID-19 pandemic. This research uses a qualitative research method of phenomenology type. The results showed that the form of a single parent's creative strategy in building a child's empathy attitude during the pandemic began with training to care for plants, animals, and helping parents at home. Whereas practicing tolerance can begin by teaching children to appreciate differences, then to practice tolerance, done by respecting the efforts and abilities of their children. Respect his child when learning to fasting even though it is not full day. This situation will make the children do things with a sense of security and comfort without having to consider the demands from parents.
\end{abstract}

Keywords: parents, empathy, COVID-19 


\section{A. Pendahuluan}

Bertambahnya kemampuan seorang anak dalam fungsi dan struktur tubuh merupakan hal yang sangat kompleks yang dapat dilalui dengan proses belajar. Aspek yang cukup penting dalam suatu perkembangan salah satunya adalah aspek kecerdasan emosional. Di dalam sebuah riset yang dilakukan oleh Dadan dan kawan-kawan, ${ }^{1}$ menyatakan bahwa terdapat kontribusi sebesar $20 \%$ bagi kecerdasan intelektual (IQ) bagi keberhasilan seseorang, sedangkan selebihnya (80\%) dipengaruhi oleh kecerdasan emosional (EQ) dan kecerdasan spiritual (SQ). Sedangkan kecerdasan emosional menurut pandangan Mashar ${ }^{2}$ mengungkapkan bahwa, contoh-contoh aspek kecerdasan emosional diantaranya yaitu self esteem, bagaimana cara seseorang dalam mengelola emosi, motivasi diri, empati, dan menjalin hubungan atau relasi dengan orang lain. Anak dapat mengembangkan kemampuan dalam berempati secara optimal di lingkungan sekolah. Namun, seperti yang diketahui bahwa saat ini, dunia pendidikan di Indonesia sedang mengalami tantangan baru disebabkan adanya wabah virus Corona. Terhitung dari bulan Maret hingga saat ini sudah mencapai 12.071 jiwa yang terkontaminasi COVID-19. ${ }^{3}$ Dan dengan melihat kondisi Indonesia yang semakin mengkhawatirkan seperti ini, membuat pemerintah mengambil kebijakan dengan menghimbau seluruh warga masyarakatnya untuk melakukan social distancing atau menjaga jarak. ${ }^{4}$ Sehingga dengan adanya kebijakan tersebut membuat seluruh aktivitas masyarakat yang dulu dilakukan di luar rumah, kini harus diberhentikan sejenak dan diganti dengan beraktivitas di rumah masing-masing.

Salah satu dampak social distancing juga terjadi pada sistem pembelajaran di sekolah. Berdasarkan Surat Edaran Nomor 4 Tahun 2020 tentang Pelaksanaan Kebijakan Pendidikan dalam Masa Darurat Penyebaran Virus, Menteri Pendidikan dan Kebudayaan menghimbau agar semua lembaga pendidikan tidak melakukan proses belajar mengajar secara tatap muka (offline) di sekolah, melainkan harus dilakukan

\footnotetext{
${ }^{1}$ Dadan Nugraha, Seni Apriliya, Riza Kharisma Veronicha, "Kemampuan Empati Anak Usia Dini, Jurnal PAUD AGAPEDIA, ”Vol. 1, No. 1 (2017): 30-39.

${ }^{2}$ R. Mashar, Emosi Anak Usia Dini dan Strategi Pengembangannya (Jakarta: Kencana, 2011), 26.

${ }^{3}$ Web Master, "Situasi Virus Corona," Covid19.go.id, n.d., https://www.covid19.go.id/situasivirus-corona/. Diakses pada 06 Mei 2020.

${ }^{4}$ Sekretariat Kabinet Republik Indonesia, “Kebijakan 'Social' dan 'Physical Distancing' Harus Libatkan Tokoh Sampai RT/RW,” diakses 06 Pada Mei 2020, https://setkab.go.id/kebijakan-social-danphysical-distancing-harus-libatkan-tokoh-sampai-rt-rw/.
} 
secara tidak langsung atau online. ${ }^{5}$ Dengan adanya himbauan tersebut membuat semua lembaga pendidikan mengganti metode pembelajaran yang digunakan yaitu menjadi online atau dalam jaringan (daring).

Hal ini tidak hanya berlaku untuk anak-anak Sekolah Menengah Atas dan Pertama saja, melainkan seluruh instansi sekolah termasuk Taman Kanak-kanak AlQur'an (TKQ) juga serentak menerapkan hal yang serupa. Berkaitan dengan permasalahan di atas, pembelajaran yang biasanya dilakukan oleh guru kini beralih kepada orang tua. Selama pembelajaran di rumah, orang tua yang bertanggung jawab dalam memberikan pembelajaran kepada anak-anaknya. Salah satunya orang tua dituntut untuk mengembangkan kreativitas anak dalam berempati. Di dalam sebuah penelitian yang dilakukan oleh Sartika dan Erni, ${ }^{6}$ terdapat beberapa faktor penghambat dalam membangun kreativitas anak usia dini. Salah satunya adalah peran keluarga. Keluarga menempatkan peran yang penting dalam menggali kreativitas anak yang tidak di dapati melalui pendidikan di sekolah. Peran keluarga merupakan salah satu peran yang sangat urgen dalam membentuk kebiasaan, watak, maupun tingkahlaku anak di lingkungan sekitarnya. Kemudian ditinjau dari hal ini, dapat menunjukkan bahwa keluarga memerankan urgensi terpenting sebagai tolak ukur dalam menumbuhkembangkan kreativitas anak. Kendala tersebut disebabkan oleh hasil dari tidak sinkronnya pengembangan kreativitas anak antara di rumah maupun di sekolah.

Sedangkan dalam meningkatkan pembelajaran empati, orang tua yang berstatus single parent boleh jadi kesusahan dalam mengajari anaknya selama era pandemi ini. Mengingat dalam masa karantina proses untuk anak bersosialisasi pun dibatasi. Di sisi lain anak yang diasuh oleh orang tua yang single parent dikhawatirkan akan mempunyai dampak yang buruk bagi perkembangannya atau pendidikannya, karena bagi orang tua single parent sangat tidak mudah dalam membagi waktu antara pekerjaan serta memenuhi kebutuhan keluarga dan anaknya. Berdasarkan uraian tersebut, dapat dipahami bahwa membangun kreativitas anak, khususnya sikap empati selama masa pandemi merupakan hal yang tidak mudah bagi orang tua yang berstatus single parent.

\footnotetext{
${ }^{5}$ Pusdiklat Pegawai Kementerian Pendidikan dan Kebudayaan, "SURAT EDARAN MENDIKBUD NO. 4 TAHUN 2020 TENTANG PELAKSANAAN KEBIJAKAN PENDIDIKAN DALAM MASA DARURAT PENYEBARAN CORONA VIRUS DISEASE (COVID-19).” Diakses pada 06 Mei 2020

${ }^{6}$ Sartika M Taher and Erni Munastiwi, "Peran Guru Dalam Mengembangkan Kreativitas Anak Usia Dini Di TK Islam Terpadu Salsabila Al-Muthi'in Yogyakarta," GOLDEN AGE: Jurnal Ilmiah Tumbuh Kembang Anak Usia Dini, Vol. 4, No. 2 (2019): 35-50
} 


\section{B. Tinjauan Teori}

\section{Empati}

Manusia merupakan makhluk sosial yang saling membutuhkan. Anak merupakan bagian dari makhluk sosial yang membutuhkan interaksi dalam kehidupan sesamanya. Di dalam agama Islam sendiri, hampir segala aspek dalam kehidupan selalu terkait dengan nilai-nilai ilahiyah, salah satunya adalah perilaku berempati. Empati merupakan sebuah keterbukaan emosi yang dialami seseorang yang mana akan mengarahkannya kepada keinginan untuk meningkatkan kesejahteraan orang lain dan mengurangi ketidaknyamanan yang dialami oleh orang lain tersebut. ${ }^{7}$

Empati merupakan perwujudan kasih sayang baik antar manusia maupun kepada sesama makhluk hidup lainnya. Terdapat hubungan antara besarnya empati dengan dengan kecenderungan perilaku menolong. Hubungan antara empati dengan perilaku menolong secara konsisten terdapat pada semua kelompok umur. Berbeda dengan simpati, yang mana perasaan simpati dapat dijumpai di setiap individu yang mampu menggambarkan perasaannya kepada orang lain. Dan perasaanya ini dipusatkan pada kondisi orang lain atau lawan bicaranya dan melakukan suatu tindakan dari orang tersebut kepada lawan bicaranya. Lain dari itu, Leslie Brothers berpendapat bahwa ketika seseorang dapat memahami emosi orang lain, di sisi lain juga dapat mengalami emosi yang sama pada kadar tertentu. ${ }^{8}$

Empati merupakan hal yang penting dalam sistem pemandu emosi yang dapat menuntun seseorang agar menjalani kestabilan emosinya dengan baik. Empati tidak hanya sekedar dalam bertahan, sebab empati merupakan suatu urgensi yang cukup penting dalam menghasilkan suatu kinerja yang istimewa dalam bidang pekerjaan yang menitik beratkan peran utamanya manusia. ${ }^{9}$ Berempati itu tidak selalu dapat dilakukan dalam bentuk memahami orang lain saja, namun juga dinyatakan atau dibuktikan secara verbal, gestur atau tingkah laku. Maka dari itu, seseorang dapat dikatakan berempati apabila adanya sebuah tindakan dalam lingkungan sosialnya. Mengingat bahwasanya empati merupakan faktor yang cukup penting dalam pembentukan sebuah interaksi

\footnotetext{
${ }^{7}$ Taufik, Empati (Pendekatan Psikologi Sosial) (Jakarta: PT Raja Grafindo Persada, 2012), 192

${ }^{8}$ K. Reivich \& A. Shaltc, The Reselience Faktor (New York: Broadway Books, 2002), 159

${ }^{9}$ Daniel Goleman, Kecerdasan Emosi untuk Mencapai Puncak Prestasi (Jakarta: PT Gramedia Pustaka Utama, 2007), 165.
} 
sosial, maka dari itu pembiasaan pembelajaran empati sejak dini dapat mempengaruhi perubahan perilaku anak ke yang lebih baik. ${ }^{10}$

Selain itu kemampuan empati anak usia golden age di taman kanak-kanak dapat terlihat dari bagaimana anak bersosialisasi dengan kawan sebayanya ketika berada di lingkungan sekolahnya. Selain itu, terdapat beberapa aspek empati yang dapat menjadi tolak ukur seberapa jauh empati yang dimiliki anak. ${ }^{11}$

\section{a. Peduli}

Peduli merupakan suatu sikap yang terdasar dari sebuah tindakan yang berdasarkan kepada perasaan yang ditunjukkan terhadap suatu masalah yang sedang dihadapi oleh orang lain. Menurut KBBI, ${ }^{12}$ peduli diartikan sebagai memperhatikan, mengindahkan, atau mencampuri suatu perkara. Orang yang peduli dapat dilihat dari keutamaan sikapnya terhadap orang lain. Orang yang peduli tidak akan berusaha untuk berbuat yang tidak baik, namun tetap berusaha untuk membantu orang lain dan berusaha menghargai orang lain.

\section{b. Toleransi}

Toleransi merupakan sikap menghargai antar individu atau antar kelompok dengan memberikan kebebasan dan memandang perbedaan sebagai suatu hak asasi manusia. Tasamuh atau toleransi artinya sama dengan maaf atau berlapang dada. Orang yang tidak mengeluh, dapat menghargai orang lain, serta lapang dada akan senantiasa menerima apa yang di dapatkannya. Contoh sikap toleransi pada anak dapat dilihat bagaimana cara pandang anak terhadap teman, apakah ia akan memandang bahwa semua kawan itu sama, apakah anak suka meminta maaf dan memaafkan kesalahan teman? Hal ini yang dapat kita lihat dari cara bagaimana anak bersosialisasi dan berinteraksi. $^{13}$

\section{c. Tenggang rasa}

Bertenggang rasa merupakan sikap saling menghormati, saling menghargai atau mengapresiasi perasaan orang lain, dan dapat menempakan diri pada situasi yang sedang dialami oleh orang lain sehingga dapat merasakannya. Sinonim dari tenggang rasa adalah "tepa sarira" yang artinya "coba rasakan dan pikirkan bila itu terjadi pada

\footnotetext{
${ }^{10}$ C. A. Budiningsih, Pembelajaran Moral (Yogyakarta: PT. Rineka Cipta, 2008), 48

${ }^{11}$ Daniel Goleman, Emotional Intelligence (Jakarta: PT Gramedia Pustaka Utama, 2016), 135.

${ }^{12}$ Peter Salim \& Yenny Salim, Kamus Besar Bahasa Indonesia Kontemporer (Jakarta: Modern English, 1991), 1171.

${ }^{13}$ Ibid., 1170.
} 
diri kamu, maka segeralah untuk menolong." Dengan tenggang rasa kita akan menjaga orang lain dari perasaan tersinggung. Individu yang berperilaku tenggang rasa akan dapat bersosialisasi dan menjalankan kodratnya sebagai makhluk sosial dengan mudah. Sehingga akan tercipta lingkungan yang sejahtera, rukun, seimbang, dan selaras. Pada anak-anak perilaku tenggang rasa dapat dilihat dari anak yang mampu menghormati setiap perbedaan yang ada pada temannya serta mampu menjaga perasaan temannya. ${ }^{14}$

Empati sangat menekankan pentingnya mengindera perasaan orang lain sebagai dasar untuk membangun hubungan sosial yang sehat antara dirinya dengan orang lain. keterbukaan emosi yang dialami seseorang akan mengarah kepada keinginan untuk meningkatkan kesejahteraan orang lain dan mengurangi ketidaknyamanan yang dialami oleh orang lain tersebut. Pada keterbangkitan emosi ini, individu menampilkan respon empati. $^{15}$

Terdapat tiga ciri kemampuan berempati yang harus dimiliki yang merupakan bagian dari kecerdasan emosional (Golleman), di antaranya: ${ }^{16}$

1) Mampu jadi pendengar: artinya, individu mampu menjadi seseorang yang dapat memberikan waktunya untuk mendengarkan keluh kesah seseorang.

2) Mampu mengerti dan mampu menerima sudut pandang dari orang lain: maksudnya adalah setiap individu dapat memandang suatu permasalahan dari titik pandang orang lain sehingga akan menimbulkan toleransi dan mempunyai kemampuan dalam menerima segenap perbedaan.

3) Mampu memahami dan reaktif terhadap perasaan orang lain: maksudnya, setiap individu dapat menganalisa serta paham akan perasaan orang lain, baik secara verbal maupun non verbal. Seperti menjaga intonasi saat berbicara agar tidak menyinggung perasaan yang sedang bercerita, memperhatikan gestur, dan bahasa tubuh lainnya.

Inti dari sikap empati adalah mampunya seseorang untuk merasakan apa yang dirasakan oleh orang lain, merasa dan berfikir bersama orang lain. Teknik mendengarkan dengan baik merupakan salah satu yang dapat dilakukan. Orang yang baik adalah orang yang dapat mendengarkan keluh kesah seseorang dengan baik dan aktif. Mampu bersikap sadar penuh hadir utuh (attending), yaitu sebagai perilaku

\footnotetext{
${ }^{14}$ Ibid., 1173.

${ }^{15}$ Daniel Goleman, Kecerdasan Emosional (Jakarta: PT Gramedia Pustaka Utama, 1996), 158

${ }^{16}$ Ibid., 219.
} 
menghampiri seseorang yang mencangkup kontak mata, bahasa badan, dan bahasa lisan. ${ }^{17}$

\section{Pandemi COVID-19}

Semenjak pertengahan tahun 2019, dunia digemparkan dengan adanya wabah virus Corona yang menyebar di dataran kota Wuhan, China. Virus yang dapat menularkan penyakit ke hewan dan manusia ini merupakan salah satu keluarga virus yang dapat sangat cepat proses penyebarannya. Kasus yang lebih parah, yang dapat terjadi kepada manusia yakni terjadinya infeksi pada sistem pernafasan Middle East Respiratory atau (MERS) serta Sindrom Pernafasan Akut Berat (SARS). Sedangkan pada beberapa kasus ringan, gejala yang muncul yakni hampir mirip seperti penyakit flu. Penyakit ini dapat mudah tersebar di ruang udara bebas melalui tetesan pernafasan seperti dari batuk atau bersin. Masa hidup virus ini dapat bertahan hingga tiga hari dalam plastik atau bahan stainless steel. SARS CoV-2 juga dapat bertahan hidup selama kurang lebih tiga jam dalam aerosol. Virus ini juga dapat ditemukan di feses, namun hingga bulan maret 2020 belum ditemukan kasus penularan virus melalui feses, dan diperkirakan bahwa resiko penularannya cukup rendah. ${ }^{18}$

Dalam keadaan parah atau kritis, pasien mungkin saja mengalami demam dari rendah hingga sedang, atau bahkan tidak didapati demam sama sekali. Gejala demam hanya hadir pada kasus yang sedikit rendah, seperti kelelahan ringan atau tanpa adanya manifestasi pneumonia. Saat ini, berdasarkan kasus yang ditangani pasien yang sehat biasanya memiliki prognosis yang baik. Sedangkan lansia, atau orang-orang yang memiliki riwayat penyakit kronis sebelumnya cenderung memiliki prognosis yang buruk, sedangkan untuk kasus anak-anak biasanya memiliki sindrom atau gejala yang relatif ringan. ${ }^{19}$

Di dalam lampiran nomor 25, tentang protokol pencegahan dan kontrol terhadap populasi tertentu untuk jenjang (Sekolah dan Taman Kanak-kanak), menjelaskan:

1) Bagi yang memiliki riwayat perjalanan ke daerah zona epidemi tinggi sangat dianjurkan untuk melakukan karantina di rumah masing-masing selama empat belas hari sebelum kembali ke sekolah.

\footnotetext{
${ }^{17}$ Ibid., 224

${ }^{18}$ ZA. Safrizal \& Danang Insita Putra, Pedoman Umum Menghadapi Pandemi COVID-19 bagi Pemerintah Daerah (Pencegahan, Pengendalian, Diagnosis, dan Management), 5

${ }^{19}$ Ibid., 6
} 
2) Apabila setelah kembali ke lingkungan sekolah, baik dari jenjang Taman Kanak-kanak hingga Perguruan Tinggi, pihak sekolah wajib memonitor suhu tubuh serta status kesehatan anak didiknya setiap hari.

3) Gunakan masker bedah medis atau N95 dengan baik dan benar saat melakukan kontak dengan guru, siswa, maupun orang lain. Serta minimalkan ruang lingkup kegiatan baik di lingkungan sekolah maupun luar sekolah.

4) Kewajiban sekolah yakni memastikan pemantauan kesehatan siswa dengan sangat amat cermat, mewajibkan mengukur suhu tubuh, menyediakan desinfektan di setiap sudut lingkungan sekolah, mencatat absen. Jika terdapat gejala yang mencurigakan di antara siswa, otoritas sekolah harus segera melaporkan kepada staff dan manajemen epidemi dnegan CDC lokal untuk melakukan manajemen desinfeksi.

5) Otoritas sekolah mewajibkan untuk menghindari penyelenggaraan pertemuan yang berskala besar, memperkuat ventilasi dan pembersihan ruang kelas, asrama, perpustakaan, pusat kegiatan, kantin, auditorium, kantor guru, toilet dan area aktivitas lainnya.

6) Otoritas sekolah untuk mengadakan pengajaran berbasis online, serta mengadakan kelas susulan dan perbaikan untuk siswa yang ketinggalan kelas dikarenakan sakit. Yakni dengan mengadakan ujian susulan. ${ }^{20}$

\section{Metode}

Metode yang digunakan pada penelitian ini adalah metode kualitatif deskriptif jenis studi kasus. Penelitian jenis studi kasus (case studies) fokus pada kasus tertentu yang perlu diamati dan analisis secara cermat dan keseluruhan terhadap individu atau kelompok sebagai subjek. ${ }^{21}$ Penelitian ini dilakukan secara daring dengan memanfaatkan teknologi yang ada. Pengumpulan data dilakukan dengan online interview dan online observation yang dibagikan subjek melalui dokumentasi instagram stories dan whatsapp stories. Adapun subjek pada penelitian ini adalah ibu AK, seorang ibu single parent yang tinggal di Bandung. AK telah bercerai dengan suaminya semenjak tahun 2016, subjek pendukung pada penelitian ini adalah UC, anak kandung

\footnotetext{
${ }^{20}$ Ibid., 172

${ }^{21}$ Sugiyono, Metode Penelitian Kuantitatif, Kualitatif, $R \& D$ (Bandung: Alfabeta, 2012).
} 
AK yang sedang bersekolah di Kelas B TKQ Hidayatul Amanah Bandung, dan saat ini berusia 6 tahun. AK dipilih menjadi subjek utama karena ia merupakan satu-satunya orang tua murid yang berstatus single parent di kelas TK B TKQ Hidayatul Amanah, hal ini di dukung dengan keabsahan data yang diterima oleh peneliti dari pihak sekolah. Untuk menguji keabsahan data, digunakan triangulasi metode dengan mengkonfirmasi kebenaran data melalui data dari sekolah.

\section{E. Hasil dan Pembahasan}

Tabel 1. Strategi kreatif orang tua single parent dalam membangun sikap empati anak selama masa pandemic Covid-19.

\begin{tabular}{|c|c|c|}
\hline Peduli & Toleransi & Tenggang Rasa \\
\hline $\begin{array}{l}\text { Mengajarkan sikap } \\
\text { peduli terhadap } \\
\text { orang yang lebih } \\
\text { tua maupun sesama } \\
\text { makhluk hidup. } \\
\text { Seperti hewan dan } \\
\text { tanaman. }\end{array}$ & $\begin{array}{l}\text { Mengajari anak untuk mengenal } \\
\text { dan menghargai bahwa perbedaan } \\
\text { antar sesame bukan dijadikan } \\
\text { bahan dan ejekan dan olokan }\end{array}$ & $\begin{array}{l}\text { Mengapresiasi hasil } \\
\text { pekerjaan dan usaha anak }\end{array}$ \\
\hline $\begin{array}{l}\text { Mengajarkan sikap } \\
\text { syukur }\end{array}$ & $\begin{array}{l}\text { Mengajari tentang apa itu } \\
\text { disabilitas atau yang memiliki } \\
\text { kekurangan fisik, dan harus siap } \\
\text { dibantu ketika ada kesempatan. }\end{array}$ & \\
\hline $\begin{array}{lr}\text { Membantu } r & \text { anak } \\
\text { mengerjakan } & \text { tugas } \\
\text { sekolah } & \end{array}$ & $\begin{array}{l}\text { Memperkenalkan } \\
\text { disabilitas melalui } \\
\text { tayangan di televise }\end{array}$ & \\
\hline $\begin{array}{l}\text { Memberikan } \\
\text { pengertian dengan } \\
\text { ucapan yang halus }\end{array}$ & & \\
\hline
\end{tabular}

Proses penyebaran dari COVID-19 sendiri berlangsung sangat cepat melalui kontaminasi seperti sentuhan fisik dan benda sebagaimana yang disampaikan oleh WHO. Melalui penyebaran ini pemerintah diseluruh dunia menghimbau kepada masyarakat untuk melakukan semua kegiatan di rumah termasuk kerja dan kegiatan belajar mengajar yang betujuan untuk memutus rantai penyebaran COVID-19. ${ }^{22}$ Empati sendiri terdiri kedalam tiga aspek yakni peduli, toleransi, dan tenggang rasa.

Peduli, merupakan sikap yang terdasar berdasarkan pada perasaan yang ditunjukkan terhadap suatu masalah yang sedang dihadapi oleh orang lain. Peduli

\footnotetext{
${ }^{22}$ Safrizal ZA \& Danang Insita Putra, Pedoman Umum ..., 8
} 
terhadap anak bisa dimulai seperti memberikan sikap keteladan yang baik, menunjukkan perilaku peduli pada orang lain, atau bahkan mendiskusikan kepedulian tersebut dengan anak, agar anak bisa terlibat aktif, tidak hanya menjadi mengamat pasif dari perilaku orang tua. Adapun bentuk kepedulian yang di lakukan selama pandemi oleh AK kepada anaknya UC yakni seperti memberi makan hewan, menyiram tanaman, mengerjakan tugas sekolahnya atau mengajak anaknya untuk membantu neneknya memasak.

Selain mencontohkan keteladanan yang baik, sikap peduli juga bisa ditunjukkan dengan berterimakasih. AK selalu memberikan ajaran sederhana kepada anaknya untuk mengucapkan terimakasih pada seseorang saat diberi sesuatu, hal ini tentunya juga bisa mendidik anak untuk bersikap empati. Anak akan mensyukuri setiap hal kecil yang di terima dari orang lain. Selain sopan, mengucapkan terimakasih juga membuat orang lain merasa dihargai.

Selama masa karantina berlangsung, AK selalu mengusahakan dirinya untuk menghabiskan waktu bersama anaknya. Sebagai orang tua yang berstatus single parent yang tinggal bersama orangtuanya, AK selalu mengajarkan UC untuk menimbang setiap perkataannya agar tak menyinggung orang lain. Misalnya, menjaga intonasi saat berbicara dengan orang yang lebih tua, meminta tolong dengan intonasi yang lembut, atau memberi pengertian kepada anaknya untuk tidak bermain di luar dengan temantemannya.

Toleransi, merupakan sikap individu maupun kelompok yang mampu memberikan suatu kebebasan dengan memandang perbedaan sebagai suatu hak asasi manusia. ${ }^{23}$ Adapun bentuk toleransi yang di lakukan oleh AK kepada anaknya sebelum memasuki sekolah, yakni dengan mengajari UC bahwa dia nanti akan bertemu dengan berbagai macam orang dengan latar belakang. Tapi perbedaan tersebut bukan dijadikan bahan ejekan atau olokan, tapi untuk memperkuat pertemanan. Seperti memperkenalkan tentang disabilitas melalui tayangan-tayangan di televisi, AK mengajari tentang disabilitas yang memiliki kekurangan fisik dan harus siap dibantu ketika ada kesempatan. Agar anaknya terbiasa untuk tidak melihat perbedaan sebagai hal yang besar.

\footnotetext{
${ }^{23}$ Peter Salim \& Yenny Salim, Kamus Besar..., 1171.
} 
Berdasarkan pembelajaran toleransi yang diterapkan subjek kepada anaknya selama masa karantina ini, maka dapat dikatakan bahwa subjek dapat mengajari anaknya untuk menghargai berbagai perbedaan ini sejak dini. Belajar memperkuat pertemanan dengan cara memperlakukan setiap teman atau orang lain yang berbeda dengan kita dengan baik tanpa ada membeda-bedakan.

Tenggang rasa, merupakan sikap menghormati atau menjunjungtinggi, menghargai perasaan orang lain, dan dapat menempakan diri pada situasi yang sedang dialami oleh orang lain sehingga dapat merasakannya. ${ }^{24}$ Sikap tenggang rasa yang subjek ajarkan kepada anaknya selama masa karantina ini dimulai dengan mengapresiasi apa yang telah anak lakukan. Seperti mengapresiasi anaknya ketika ia berhasil belajar berpuasa walaupun hanya setengah hari.

Sikap tenggang rasa yang dilakukan AK kepada anaknya, ternyata dilakukan dengan cara menghargai usaha dan kemampuan yang dilakukan oleh anaknya. Menghargai anaknya ketika ia sedang belajar berpuasa meskipun tidak full day. Hal ini tentunya membuat anak melakukan sesuatunya dengan rasa aman dan nyaman tanpa harus di beratkan dengan tuntutan dari orang tua.

\section{F. Simpulan}

Strategi kreatif orang tua yang berstatus single parent dalam membangun sikap empati selama masa pandemi dapat diimplementasikan ke dalam tiga aspek yakni, dengan menerapkan sikap peduli, toleransi, dan tenggang rasa. Sikap peduli, bisa dicontohkan seperti membantu orang tua dan peduli terhadap sesama makhluk hidup. Selain itu sikap peduli juga bisa ditunjukan dengan berterimakasih, menjaga intonasi saat berbicara dengan orang yang lebih tua, meminta tolong dengan intonasi yang lembut, atau memberi pengertian kepada anaknya untuk tidak bermain di luar dengan teman-temannya selama masa karantina.

Adapun bentuk toleransi yang dilakukan yakni dengan mengajari bahwa anak akan menemukan berbagai macam orang dengan latar belakang yang berbeda. Tapi segala perbedaan tersebut tidak bolehs dijadikan sebagai bahan ejekan atau olokan, tetapi sebagai jalan untuk memperkuat pertemanan. Selain itu, dengan memperkenalkan

\footnotetext{
${ }^{24}$ Ibid., 1173.
} 
tentang disabilitas melalui tayangan-tayangan di televisi, agar sang anak dapat terbiasa untuk tidak melihat perbedaan sebagai hal yang besar.

Sikap tenggang rasa yang dapat diajarkan selama masa karantina ini dimulai dengan mengapresiasi apa yang telah anak lakukan. Seperti mengapresiasi anak ketika ia berhasil belajar berpuasa walaupun hanya setengah hari. Sikap tenggang rasa yang dilakukan AK kepada anaknya, ternyata dilakukan dengan cara menghargai usaha dan kemampuan yang dilakukan oleh anaknya. Menghargai anaknya ketika ia sedang belajar berpuasa meskipun tidak full day. Hal ini tentunya membuat anak melakukan sesuatunya dengan rasa yang aman dan nyaman tanpa harus di beratkan dengan tuntutan dari orang tua.

\section{G. Daftar Pustaka}

Budiningsih, C. A. Pembelajaran Moral. Yogyakarta: PT. Rineka Cipta, 2008.

Goleman, Daniel. Emotional Intelligence. Jakarta: PT Gramedia Pustaka Utama, 2016.

Goleman, Daniel. Kecerdasan Emosi untuk Mencapai Puncak Prestasi. Jakarta: PT Gramedia Pustaka Utama, 2007.

Goleman, Daniel. Kecerdasan Emosional. Jakarta: PT Gramedia Pustaka Utama, 1996

Mashar, R. Emosi Anak Usia Dini dan Strategi Pengembangannya. Jakarta: Kencana, 2011.

Master, Web. "Situasi Virus Corona." Covid19.go.id, n.d., https://www.covid19.go.id/situasi-virus-corona/. Diakses pada 06 Mei 2020.

Nugraha, Dadan; Seni Apriliya; dan Riza Kharisma Veronicha. "Kemampuan Empati Anak Usia Dini," Jurnal PAUD AGAPEDIA, " Vol. 1, No. 1 (2017): 30-39.

Pusdiklat Pegawai Kementerian Pendidikan dan Kebudayaan. "SURAT EDARAN MENDIKBUD NO. 4 TAHUN 2020 TENTANG PELAKSANAAN KEBIJAKAN PENDIDIKAN DALAM MASA DARURAT PENYEBARAN CORONA VIRUS DISEASE (COVID-19).” Diakses pada 06 Mei 2020

Reivich, K. \& A. Shaltc, The Reselience Faktor. New York: Broadway Books, 2002.

Safrizal, ZA \& Danang Insita Putra. Pedoman Umum Menghadapi Pandemi COVID-19 bagi Pemerintah Daerah (Pencegahan, Pengendalian, Diagnosis, dan Management).

Salim, Peter \& Yenny Salim. Kamus Besar Bahasa Indonesia Kontemporer. Jakarta: Modern English, 1991.

Sekretariat Kabinet Republik Indonesia. "Kebijakan 'Social' dan 'Physical Distancing' Harus Libatkan Tokoh Sampai RT/RW.” https://setkab.go.id/kebijakan-socialdan-physical-distancing-harus-libatkan-tokoh-sampai-rt-rw/. Diakses 06 Pada Mei 2020 
Sari Puteri Deta Larastati \& Erni Munastiwi: Strategi Kreatif Orang Tua Single Parent dalam Membangun Sikap Empati Anak Selama Masa Pandemi COVID-19

Taher, Sartika M. \& Erni Munastiwi. "Peran Guru dalam Mengembangkan Kreativitas Anak Usia Dini di TK Islam Terpadu Salsabila Al-Muthi' in Yogyakarta." GOLDEN AGE: Jurnal Ilmiah Tumbuh Kembang Anak Usia Dini, Vol. 4, No. 2 (2019): 35-50

Taufik. Empati (Pendekatan Psikologi Sosial). Jakarta: PT Raja Grafindo Persada, 2012. 